ORIGINAL ARTICLE

\title{
Psychosocial work environment and indoor air problems: a questionnaire as a means of problem diagnosis
}

\author{
M Lahtinen, C Sundman-Digert, K Reijula
}

Occup Environ Med 2004;61:143-149. doi: 10.1136/oem.2002.005835

See end of article for authors' affiliations

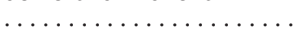

Correspondence to: Dr M Lahtinen, Finnish Institute of Occupational Health, Uusimaa Regional Institute, Arinatie 3 a, FIN00370 Helsinki, Finland; marjaana.lahtinen@ occuphealth.fi

Accepted 31 March 2003

\begin{abstract}
Aims: To examine the relation between the psychosocial work environment and the perceived indoor air problems measured by a questionnaire survey; and to discuss the role of a questionnaire as a means to enhance collaboration in the challenging multiprofessional process of solving indoor air problems.

Methods: The research material comprises surveys conducted in 1996-99 in 122 office workplaces with 11154 employees.

Results: The association between the psychosocial work environment measured by the Indoor Air Questionnaire (MM-40) and the occupants' complaints concerning indoor air as well as symptoms attributed to indoor air was significant. Those who perceived their psychosocial work environment more negatively had more complaints regarding the indoor environment and more symptoms attributed to the indoor air. The association was detected among both genders, in every age group, among smokers and non-smokers, and respondents with an allergic or a non-allergic background.

Conclusions: Results support the hypothesis that psychosocial factors in the work environment play a significant role in indoor air problems at workplaces. The survey data can be used as a reference database for future studies, and in occupational health care practice when the working conditions of individual workplaces are estimated. The MM-40 could be useful as a practical screening method in field work for analysing the role of the psychosocial work environment among the different background factors of an indoor air problem. However, in order to interpret and evaluate the significance of the results concerning a single workplace, more information on the organisation is needed, as well as cooperation and discussions with the staff. Further studies of the reliability and validity of the psychosocial questions in $M M-40$ are also needed.
\end{abstract}

A $\mathrm{n}$ indoor air problem can be considered one of the problem solving tasks that an organisation may face. One of the central phases in the problem solving process is to diagnose the problem-that is, to attempt to specify the probable nature of the problem. This phase requires sufficient information about the problem, a frame of reference within which the analysis takes place, and a proper language with which the problem situation can be described and defined. ${ }^{1}$ The diagnosis involves developing a mental model of the problem: naming the problem, finding reasons for its existence, suggesting ways to solve it, and predicting what might happen if the problem remains unsolved. ${ }^{2}$ The common model is based on the acquired information, individual interpretations, and mutual interaction. Defining the problem in a group is a complex process, vulnerable to misunderstandings and affected by various beliefs, values, goals, and norms, as well as conflicts, which often arise. ${ }^{23}$

The complexity accumulates, especially if the problem management requires multiprofessional collaboration, as is often the case with indoor air problems. Lyles ${ }^{4}$ makes a distinction between well defined and ill defined problems. Ill defined problems typically manifest themselves in a variety of ways. People perceive them differently, and their character can be debatable. In ill defined problems, the problem diagnosis easily becomes an essential part of the process. Indoor air problems in office environments often meet the criteria of ill defined problems. ${ }^{5}$ In many cases, an indoor air problem is of multifactorial origin, developing from the interaction of the chemical, physical, biological, and psychosocial factors in the work environment. People's individual characteristics and behaviour also partly explain the outcome of the problem. According to recent studies, such psychosocial factors as work overload, high time pressure, lack of possibilities to control one's work situation, lack of social support, poor interpersonal relationships, role ambiguity, and role conflict can aggravate the symptoms and complaints attributed to indoor air problems at work. ${ }^{67}$ Mental strain and work related stress thus seem to serve as a modifying factor between environmental factors and symptoms, increasing an individual's sensitivity to the physical, chemical, and biological hazards of the work environment. Recently, some theoretical models which emphasise the interaction of the physical and psychosocial factors in the work environment have been proposed. ${ }^{8}{ }^{9}$ Furthermore, stress itself can result in physiological and physical responses and health complications, which resemble the symptoms related to indoor air problems. ${ }^{10}$

According to Lahtinen and colleagues, ${ }^{5}$ typical difficulties in the diagnosis of an indoor air problem at workplaces were connected to inadequate information and the use of different frames of reference when interpreting the available facts. Different parties-superiors, employees, health and safety personnel, technical personnel, external experts, and building owners-with their different roles, expectations, and goals, had very diverse perceptions of the quality of the problem and its significance on health. Consequently, a common mental model of the indoor air problem was not achieved in the studied organisations. This led to interpersonal conflict situations which reflected in the way the problem was managed, and complicated the problem solving process further. It was typical that the characteristics of the psychosocial work environment were frequently mentioned as one cause or background factor behind the indoor air problem, but this hypothesis was not investigated systematically. Psychosocial explanations for health complaints were diagnosed simply by exclusion, when no other 
Main messages

- Indoor air problems are of multifactorial origin and, in many cases, the psychosocial work environment also plays a significant role in the outcome of the problem.

environmental causes and explanations seemed to be satisfactory.

Methods facilitating the diagnosis phase in a situation of complex and multiple exposure are needed to support the multiprofessional collaboration that is vital in solving indoor air problems. A questionnaire widely used in the Nordic countries, which also includes items concerning the psychosocial work environment, is the MM-40, developed by Andersson and his colleagues in Örebro, Sweden. ${ }^{11}$ The Finnish translation of the MM-40 has been used and evaluated by the Finnish Institute of Occupational Health since 1995. It is a commonly used tool of occupational health services for investigating indoor air problems at workplaces. The questionnaire helps to assess the extent of the indoor air problem, the urgency of the measures needed, and their direction.

The MM-40 is used for studying the participants' experiences on the quality of the indoor air and the conditions at the workplace, as well as on the symptoms attributed to the work environment. The collected background information includes, for example, the previous and current allergic diseases and the smoking habits of the employees. In addition, the questionnaire includes a series of four questions exploring briefly the psychosocial work environment.

The questions concerning the psychosocial work environment included in the MM-40 refer to the quantitative and qualitative workload, possibilities to control one's work situation, and to receive social support. The selected questions are based on the long term development work by the Swedish research group. ${ }^{11}$ The selection is also well grounded in the light of stress theories. The central roles of work demand, control, and social support on individual wellbeing and health have been shown in many studies and are in accordance with the job demands-job control model of Karasek and colleagues. ${ }^{12-14}$ The four dimensions do not cover the whole scope of the psychosocial work environment. The questionnaire does not give any information, for instance, about such important factors as clarity of the work role, supervision, organisational culture and function, or insecurity caused by organisational changes and crises. However, the questions in MM-40 monitor the psychosocial work environment and the risk factors of work related stress from one important angle.

Although the MM-40 questionnaire is widely used, only few studies have reported data concerning the psychosocial questions. In this study we examined the relation between the psychosocial work environment and the perceived indoor air problems measured by the MM-40 questionnaire. In addition, we discuss the MM-40 questionnaire as a means to enhance collaboration in the challenging multiprofessional process of solving indoor air problems.

The results of the study on the prevalence of complaints concerning indoor air and the symptoms of workers have been reported elsewhere. ${ }^{15}$

\section{METHODS}

The present material comprises MM-40 questionnaire surveys conducted in southern Finland by the Uusimaa Regional Institute of Occupational Health in 1996-99. The survey was conducted at 122 workplaces from which a total of 11154

\section{Policy implications}

- When indoor air problems are tackled, methods are needed to facilitate the diagnosis phase and to support the multiprofessional collaboration. In order to achieve good results with indoor air problems, it may be necessary to apply restorational measures and interventions, directed at both the technical and psychosocial work environment, and the work organisation.

employees returned the completed questionnaire. The workplaces were mainly offices. In addition, nine schools, four hospitals or health care centres, and 14 other workplaces were investigated. Seventy per cent of the subjects were women. The average response rate was $73 \%$. The workplaces had contacted their occupational health service to investigate the building due to suspicion of an indoor air problem.

The psychosocial work environment was investigated using the MM-40 with the following questions:

- Do you regard your work as interesting and stimulating?

- Do you have too much work to do?

- Do you have any opportunity to influence your working conditions?

- Do your fellow workers help you with problems you may have in your work?

There were four alternative response categories to the questions: 1, yes, often; 2, yes, sometimes; 3, no, seldom; or 4, no, never.

Problems in the work environment (for example, draught, dry and stuffy air, etc; altogether 12 items) were recalled from the past three months ( 1 , yes, often, every week; 2 , yes, sometimes; 3, no, never). Symptoms related to the indoor air at work ( 12 items) were also inquired about for the past three months (1, yes, often, every week; 2, yes, sometimes; 3 , no, never), and it was asked whether the participant attributed them to the work environment. In the present study, the evaluation focused on symptoms that were considered work related.

The characteristics of the psychosocial work environment were observed through percentage distributions. Differences between the sexes and age groups were tested with the $\chi^{2}$ compatibility test, which was also used for investigating the association between the psychosocial work environment and complaints of environmental factors, and also the association between the psychosocial work environment and symptoms related to indoor air.

The multivariate analyses of variance were computed to examine the interaction effects between the psychosocial work environment and gender, age, smoking habits, and allergic background. For this reason, several sum variables were calculated. The sum variable of "the psychosocial work environment" comprised the four questions described above; it was calculated by forming the sum of the values $1-4$ assigned to the alternatives for each question (range 4-16, "too much work to do" in reverse order). Furthermore, it was divided into three classes: few stress factors (a sum of less than 6 , comprising $30 \%$ of the data); moderate stress factors (a sum of $7-8$, comprising $45 \%$ of the data); and plenty of stress factors at work (a sum of 9-15, comprising $25 \%$ of the data).

The scale of "the complaints about the indoor air" was calculated as a sum of the 12 items describing various problems in the work environment. The values attached to the alternatives were: $0=$ no, never; $1=$ yes, sometimes; 2 = yes, often, every week (range 0-24). 
Finally, three sum variables were calculated of the symptoms related to indoor air. "General symptoms" included five items: fatigue, feeling heavy headed, headache, nausea/dizziness, and difficulties in concentrating. The values attached to the alternatives were: $0=$ no, never (or a symptom not related to work); $1=$ yes, sometimes (work related); 2 = yes, often (work related), every week (range 0 10). "Mucous membrane symptoms" comprises the responses to the following four individual questions: irritation of the eyes; irritated, stuffy, or runny nose; hoarse or dry throat; and cough (see above for the values attached, range 0-8). "Dermal symptoms" were studied with three items: dry or flushed facial skin; scaling/itching scalp or ears and hands dry; itching or red skin (see above for the values attached, range 0-6).

The sum variables were also used for calculating Pearson's correlation coefficients on the level of the workplace using all cases as single points. For the statistical processing of the data, the SAS 8.2 statistical program was used.

\section{RESULTS}

\section{The psychosocial work environment}

Regarding one's work as interesting and stimulating, in addition to possibilities of receiving social support at work, are central resources which increase mental wellbeing. ${ }^{12-14}$ In the present study, a majority of the respondents $(75 \%)$ perceived their work as being often interesting (table 1). Seventy two per cent of the respondents often received help from their colleagues in problem situations at work. Women regarded the contents of their work and social support slightly more positively than did men.

The most common causes of psychological overload and stress are haste and time pressure. In the present study every fifth respondent estimated their workload as often too great, and 59\% estimated that they sometimes had too much work to do (table 1). Concerning quantitative workload, there were no differences between the genders.

It is typical for people to try to maintain the sense of control over their immediate environment. The possibilities to control one's own work situation also help significantly to adjust the workload to one's mental state. In this study 35\% of the respondents estimated that they could often influence their working conditions (table 1). Men perceived their control possibilities to be better than did women.

In the youngest age group (fig 1), work was regarded as interesting and stimulating less frequently than in the older age groups. In addition, possibilities to control one's working conditions were also regarded less than in the other groups. Too big a workload, however, was rare, and receiving social support when needed was regarded as easier in the younger age group. Perceiving work as interesting and possibilities to influence increased with age. The differences between the age groups were statistically significant. Those who experienced their workload as too heavy were most often in the age group 45-54 years.

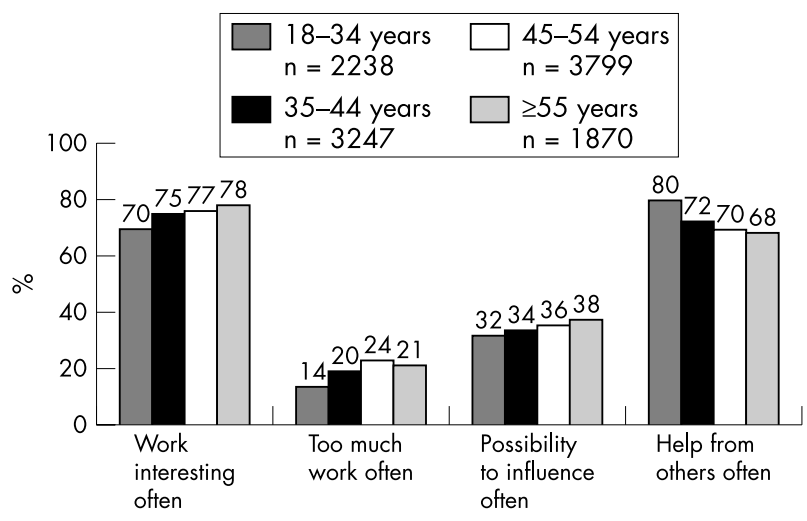

Figure 1 The psychosocial work environment of different age groups ( $n=11$ 154).

\section{The psychosocial work environment and indoor air complaints}

The results of the survey clearly point to a connection between the psychological work environment and complaints about the indoor air (table 2). Those who felt that their work was never interesting, who had too great a workload, and who experienced their possibilities to control as minor, reported significantly more complaints about the indoor air and the environment. The relation between social support and complaints of indoor air factors was not as clear. However, those who reported that they rarely or never received help from their colleagues, complained most often about dust and draught in the work environment, smoking by others, unpleasant odours, noise, and problems with the illumination.

The multivariate analyses of variance were calculated to examine whether the psychosocial work environment had similar associations with the complaints about the indoor air of male and female respondents, respondents of different ages, smokers and non-smokers, or allergic background. The data showed that all of the independent variables mentioned above had a statistically significant main effect, but no interaction effects (for the associations of sex, age, smoking habits, and allergic background with the complaints on indoor air see Reijula and Sundman-Digert ${ }^{15}$ ). Hence, the psychosocial work environment had similar effects on the quantity of the complaints concerning indoor air among both men and women, younger and older age groups, smokers and non-smokers, and respondents with or without an allergic background.

Pearson's correlation coefficients were calculated using the sum variables to check the data from the level of each individual workplace. It was possible to make the check in 112 of the studied workplaces. The correlation between the psychosocial work environment and the complaints about the

Table 1 Perceived psychosocial work environment in 122 office workplaces; percentages of male $(n=3240)$ and female $(n=7819)$ respondents (gender not reported in 95 responses)

\begin{tabular}{|c|c|c|c|c|c|c|c|c|c|c|}
\hline & \multicolumn{3}{|c|}{ Often } & \multicolumn{3}{|c|}{ Sometimes } & \multicolumn{3}{|c|}{ Seldom/never } & \multirow[b]{2}{*}{ p value* } \\
\hline & $\begin{array}{l}\text { All } \\
\%\end{array}$ & $\begin{array}{l}\text { Women } \\
\%\end{array}$ & $\begin{array}{l}\text { Men } \\
\%\end{array}$ & $\begin{array}{l}\text { All } \\
\%\end{array}$ & $\begin{array}{l}\text { Women } \\
\%\end{array}$ & $\begin{array}{l}\text { Men } \\
\%\end{array}$ & $\begin{array}{l}\text { All } \\
\%\end{array}$ & $\begin{array}{l}\text { Women } \\
\%\end{array}$ & $\begin{array}{l}\text { Men } \\
\%\end{array}$ & \\
\hline Work interesting and stimulating & 75 & 76 & 73 & 20 & 19 & 23 & 4 & 4 & 5 & 0.001 \\
\hline Too much work to do & 20 & 20 & 20 & 59 & 59 & 59 & 21 & 21 & 21 & 0.983 \\
\hline $\begin{array}{l}\text { Opportunity to influence working } \\
\text { conditions }\end{array}$ & 35 & 31 & 46 & 44 & 46 & 39 & 21 & 24 & 16 & 0.001 \\
\hline Help from fellow workers & 72 & 74 & 68 & 22 & 20 & 25 & 6 & 6 & 7 & 0.001 \\
\hline
\end{tabular}


Table 2 Association of the psychosocial work environment with indoor air complaints among office employees $(n=11154)$.

\begin{tabular}{|c|c|c|c|c|c|c|c|c|c|c|c|c|}
\hline & $\begin{array}{l}\text { Work } \\
\text { interesting } \\
\text { often } \\
\%\end{array}$ & $\begin{array}{l}\text { Work } \\
\text { interesting } \\
\text { seldom/never } \\
\%\end{array}$ & p & $\begin{array}{l}\text { Too } \\
\text { much } \\
\text { work } \\
\text { often } \\
\%\end{array}$ & $\begin{array}{l}\text { Too much } \\
\text { work } \\
\text { seldom/ } \\
\text { never } \\
\%\end{array}$ & $\mathbf{p}$ & $\begin{array}{l}\text { Possibility } \\
\text { to influence } \\
\text { often } \\
\%\end{array}$ & $\begin{array}{l}\text { Possibility } \\
\text { to influence } \\
\text { seldom/ } \\
\text { never } \\
\%\end{array}$ & $\mathbf{p}$ & $\begin{array}{l}\text { Help } \\
\text { from the } \\
\text { others } \\
\text { often } \\
\%\end{array}$ & $\begin{array}{l}\text { Help from } \\
\text { the others } \\
\text { seldom/never } \\
\%\end{array}$ & $p$ \\
\hline \multicolumn{13}{|l|}{ Draught } \\
\hline Every week & 21 & 30 & & 22 & 21 & & 16 & 30 & & 22 & 26 & \\
\hline No, never & 36 & 27 & 0.001 & 36 & 37 & 0.003 & 43 & 26 & 0.001 & 34 & 32 & 0.025 \\
\hline \multicolumn{13}{|c|}{ Temperature too high } \\
\hline Every week & 18 & 21 & & 18 & 14 & & 14 & 23 & & 17 & 18 & \\
\hline No, never & 34 & 35 & NS & 34 & 39 & 0.001 & 39 & 29 & 0.001 & 34 & 37 & NS \\
\hline \multicolumn{13}{|c|}{ Temperature varies } \\
\hline Every week & 15 & 23 & & 18 & 13 & & 13 & 23 & & 16 & 18 & \\
\hline No, never & 32 & 27 & 0.001 & 30 & 35 & 0.001 & 37 & 25 & 0.001 & 31 & 32 & NS \\
\hline \multicolumn{13}{|c|}{ Temperature too low } \\
\hline Every week & 13 & 20 & & 13 & 12 & & 10 & 17 & & 13 & 14 & \\
\hline No, never & 36 & 33 & 0.001 & 36 & 40 & 0.002 & 42 & 31 & 0.001 & 36 & 35 & NS \\
\hline \multicolumn{13}{|l|}{ Stuffy air } \\
\hline Every week & 34 & 41 & & 38 & 30 & & 26 & 44 & & 34 & 37 & \\
\hline No, never & 24 & 16 & 0.001 & 23 & 26 & 0.001 & 32 & 16 & 0.001 & 24 & 24 & NS \\
\hline \multicolumn{13}{|l|}{ Dry air } \\
\hline Every week & 35 & 44 & & 40 & 30 & & 28 & 43 & & 35 & 37 & \\
\hline No, never & 26 & 19 & 0.001 & 24 & 31 & 0.001 & 34 & 19 & 0.001 & 26 & 25 & NS \\
\hline \multicolumn{13}{|c|}{ Unpleasant odour } \\
\hline Every week & 16 & 25 & & 19 & 14 & & 12 & 23 & & 16 & 23 & \\
\hline No, never & 39 & 30 & 0.001 & 37 & 41 & 0.001 & 46 & 28 & 0.001 & 38 & 35 & 0.001 \\
\hline \multicolumn{13}{|l|}{ Static electricity } \\
\hline Every week & 7 & 11 & & 8 & 6 & & 5 & 10 & & 8 & 9 & \\
\hline No, never & 63 & 57 & 0.002 & 61 & 69 & 0.001 & 68 & 55 & 0.001 & 62 & 56 & 0.047 \\
\hline \multicolumn{13}{|l|}{ Passive smoking } \\
\hline Every week & 3 & 6 & & 5 & 2 & & 3 & 5 & & 3 & 7 & \\
\hline No, never & 81 & 79 & NS & 79 & 84 & 0.001 & 83 & 78 & 0.001 & 82 & 76 & 0.001 \\
\hline \multicolumn{13}{|l|}{ Noise } \\
\hline Every week & 16 & 30 & & 21 & 13 & & 12 & 26 & & 17 & 20 & \\
\hline No, never & 45 & 30 & 0.001 & 40 & 50 & 0.001 & 54 & 30 & 0.001 & 44 & 39 & 0.001 \\
\hline \multicolumn{13}{|c|}{ Illumination problems } \\
\hline Every week & 13 & 24 & & 17 & 10 & & 9 & 22 & & 13 & 18 & \\
\hline No, never & 50 & 39 & 0.001 & 44 & 57 & 0.001 & 60 & 36 & 0.001 & 50 & 43 & 0.001 \\
\hline \multicolumn{13}{|l|}{ Dust or dirt } \\
\hline Every week & 24 & 42 & & 30 & 21 & & 19 & 37 & & 25 & 30 & \\
\hline No, never & 35 & 21 & 0.001 & 38 & 41 & 0.001 & 42 & 24 & 0.001 & 35 & 28 & 0.001 \\
\hline
\end{tabular}

indoor air ranged from no correlation to 0.70 in the workplaces. In $41 \%$ of the workplaces a statistically significant $(\mathrm{p}<0.05)$ positive correlation was found. No statistically significant negative correlation was found between psychosocial work environment and the complaints in any workplace.

\section{The psychosocial work environment and symptoms}

The present data refer to a connection between the psychosocial work environment and symptoms attributed to the indoor air as well. There was a statistically significant connection between lack of interest in work, the workload being too great, and the lack of possibilities for control, and most of the symptoms attributed to the indoor air (table 3 ). The connection was not as clear concerning symptoms such as dry throat, cough, and scaling of the scalp. The lack of social support was connected mainly to general symptoms (fatigue, feeling heavy headed, headache, nausea, problems in concentrating).

Furthermore, the multivariate analyses of variance were calculated to examine whether the psychosocial work environment had similar associations to the symptoms of male and female respondents, respondents of different ages, smokers and non-smokers, or allergic background. Table 4 shows that general symptoms were more clearly connected with the psychosocial work environment among women than among men. Correspondingly, no interaction effect was found concerning mucous membrane or dermal symptoms.
In addition to this, only one other interaction effect was found. The multivariate analyses showed a tendency $(\mathrm{p}<0.05)$ for dermal symptoms to be more clearly connected with the psychosocial work environment in the younger age group ( $18-44$ years) than in the older one ( $\geqslant 45$ years).

At the level of each workplace $(n=112)$ the correlation between the psychosocial work environment and the indoor air symptoms ranged from no correlation to 0.85 (general symptoms), to 0.78 (dermal symptoms), and to 0.65 (mucous membrane symptoms). A statistically significant $(p<0.05)$ positive correlation between the psychosocial work environment and at least one of the symptom sum variables was found in $61 \%$ of the studied workplaces. A statistically significant negative association was found in one workplace between the psychosocial work environment and the dermal symptoms, and in three workplaces between the psychosocial work environment and the mucous membrane symptoms.

In 16 workplaces the psychosocial work environment had a correlation of $>0.30$ with the complaints about indoor air and, at the same time, a correlation of $>0.30$ with at least two of the symptom sum variables. This group of workplaces with a strong multiple association (table 5) was compared to the group of workplaces with moderate or weak association (the rest of the data). The results showed that the association of the psychosocial work environment with the indoor air complaints and symptoms was strongest at the workplaces where the prevalence of experienced indoor air problems was the highest. 


\begin{tabular}{|c|c|c|c|c|c|c|c|c|c|c|c|c|}
\hline & $\begin{array}{l}\text { Work } \\
\text { interesting } \\
\text { often } \\
\%\end{array}$ & $\begin{array}{l}\text { Work } \\
\text { interesting } \\
\text { seldom/never } \\
\%\end{array}$ & p & $\begin{array}{l}\text { Too } \\
\text { much } \\
\text { work } \\
\text { often } \\
\%\end{array}$ & $\begin{array}{l}\text { Too much } \\
\text { work } \\
\text { seldom/ } \\
\text { never } \\
\%\end{array}$ & $p$ & $\begin{array}{l}\text { Possibility to } \\
\text { influence } \\
\text { often } \\
\%\end{array}$ & $\begin{array}{l}\text { Possibility to } \\
\text { roinfluence } \\
\text { seldom/ } \\
\text { never } \\
\%\end{array}$ & $p$ & $\begin{array}{l}\text { Help } \\
\text { from } \\
\text { others } \\
\text { often } \\
\%\end{array}$ & $\begin{array}{l}\text { Help from } \\
\text { others } \\
\text { seldom/never } \\
\%\end{array}$ & $r$ \\
\hline \multicolumn{13}{|l|}{ Fatigue } \\
\hline $\begin{array}{l}\text { Every week, work } \\
\text { related }\end{array}$ & 14 & 35 & & 27 & 10 & & 10 & 27 & & 14 & 27 & \\
\hline $\begin{array}{l}\text { No, never } \\
\text { Feeling heavy headed }\end{array}$ & 65 & 49 & 0.001 & 54 & 74 & 0.001 & 73 & 50 & 0.001 & 65 & 54 & 0.001 \\
\hline $\begin{array}{l}\text { Every week, work } \\
\text { related }\end{array}$ & 9 & 20 & & 14 & 6 & & 6 & 16 & & 9 & 14 & \\
\hline $\begin{array}{l}\text { No, never } \\
\text { Headache }\end{array}$ & 67 & 55 & 0.001 & 60 & 74 & 0.001 & 74 & 56 & 0.001 & 67 & 61 & 0.001 \\
\hline $\begin{array}{l}\text { Every week, work } \\
\text { related }\end{array}$ & 6 & 13 & & 10 & 5 & & 4 & 12 & & 6 & 11 & \\
\hline $\begin{array}{l}\text { No never } \\
\text { Nausea/dizziness }\end{array}$ & 69 & 61 & 0.001 & 64 & 74 & 0.001 & 76 & 59 & 0.001 & 69 & 64 & 0.001 \\
\hline $\begin{array}{l}\text { Every week, work } \\
\text { related }\end{array}$ & 1 & 5 & & 2 & 1 & & 1 & 3 & & 1 & 4 & \\
\hline $\begin{array}{l}\text { No. Never } \\
\text { Difficulties concentratin }\end{array}$ & 92 & 81 & 0.001 & 88 & 93 & 0.001 & 94 & 84 & 0.001 & 91 & 86 & 0.001 \\
\hline $\begin{array}{l}\text { Every week, work } \\
\text { related }\end{array}$ & 3 & 11 & & 8 & 2 & & 2 & 7 & & 3 & 9 & \\
\hline $\begin{array}{l}\text { No never } \\
\text { Irritation of the eyes }\end{array}$ & 76 & 65 & 0.001 & 66 & 84 & 0.001 & 82 & 65 & 0.001 & 77 & 64 & 0.001 \\
\hline $\begin{array}{l}\text { Every week, work } \\
\text { related }\end{array}$ & 17 & 25 & & 20 & 15 & & 14 & 22 & & 17 & 21 & \\
\hline $\begin{array}{l}\text { No never } \\
\text { Irritated, stuffy, runny } \\
\text { nose }\end{array}$ & 57 & 52 & 0.001 & 57 & 61 & 0.001 & 63 & 50 & 0.001 & 57 & 55 & 0.05 \\
\hline $\begin{array}{l}\text { Every week, work } \\
\text { related }\end{array}$ & 20 & 28 & & 21 & 17 & & 17 & 25 & & 19 & 24 & \\
\hline $\begin{array}{l}\text { No, never } \\
\text { Hoarse, dry throat }\end{array}$ & 58 & 51 & 0.001 & 56 & 62 & 0.001 & 63 & 51 & 0.001 & 58 & 57 & 0.01 \\
\hline $\begin{array}{l}\text { Every week, work } \\
\text { related }\end{array}$ & 14 & 20 & & 16 & 12 & & 11 & 18 & & 14 & 17 & \\
\hline $\begin{array}{l}\text { No, never } \\
\text { Cough }\end{array}$ & 62 & 56 & 0.01 & 60 & 66 & 0.001 & 66 & 55 & 0.001 & 61 & 61 & NS \\
\hline $\begin{array}{l}\text { Every week, work } \\
\text { related }\end{array}$ & 5 & 8 & & 6 & 4 & & 4 & 7 & & 5 & 6 & \\
\hline $\begin{array}{l}\text { Every week, work } \\
\text { related }\end{array}$ & ${ }^{n} 11$ & 18 & & 14 & 9 & & 9 & 15 & & 11 & 14 & \\
\hline $\begin{array}{l}\text { No, never } \\
\text { Scaling/itching scalp o } \\
\text { ears }\end{array}$ & 75 & 68 & 0.001 & 72 & 78 & 0.001 & 78 & 71 & 0.001 & 74 & 72 & NS \\
\hline $\begin{array}{l}\text { Every week, work } \\
\text { related }\end{array}$ & 7 & 10 & & 8 & 6 & & 5 & 9 & & 7 & 10 & \\
\hline $\begin{array}{l}\text { No never } \\
\text { Hands dry, itching, red } \\
\text { skin }\end{array}$ & 86 & 80 & 0.01 & 84 & 88 & 0.001 & 88 & 82 & 0.001 & 86 & 83 & NS \\
\hline $\begin{array}{l}\text { Every week, work } \\
\text { related }\end{array}$ & 15 & 27 & & 18 & 14 & & 12 & 23 & & 17 & 16 & \\
\hline No never & 70 & 58 & 0.001 & 69 & 71 & 0.001 & 76 & 61 & 0.001 & 67 & 70 & 0.01 \\
\hline
\end{tabular}

\section{DISCUSSION}

The results of the present survey on the characteristics of the psychosocial work environment are consistent with a recent large national interview study from Finland. ${ }^{16}$ The questions used in these two surveys cannot be directly compared, but a similar overall view is evident in both of them. Too great a workload is a common stress factor among employees in Finland, among both men and women. On average, four out of five employees have to hurry at least every now and then to get their work done. Work itself and social support were generally assessed positively. In the present study, women regarded the contents of work and social support slightly more positively than did men. Both surveys showed that men consider their possibilities for influence clearly better than women.
The older age groups evaluated the contents of work more positively than the youngest age group, while the respondents in the youngest age group experienced less time pressure and received better social support and help when needed. It is natural that, as age, work experience, and competence increase, work assignments become more complex and challenging. As experience accumulates, more independent work roles are adopted and, as a result, possibilities to influence one's work increase, and simultaneously the need for help from colleagues partially decreases.

The present study clearly confirms the results of earlier studies and the hypothesis about the multifactorial background of indoor air problems. The psychosocial factors in the work environment play a significant role in the indoor air problems at workplaces: those who experience their 
Table 4 Effects of the psychosocial work environment and gender on the symptoms attributed to indoor climate

\begin{tabular}{|c|c|c|c|c|c|c|c|c|c|c|c|c|}
\hline & \multicolumn{4}{|c|}{ General symptoms } & \multicolumn{4}{|c|}{ Mucous membrane symptoms } & \multicolumn{4}{|c|}{ Dermal symptoms } \\
\hline & \multicolumn{2}{|l|}{ Men } & \multicolumn{2}{|c|}{ Women } & \multicolumn{2}{|l|}{ Men } & \multicolumn{2}{|c|}{ Women } & \multicolumn{2}{|l|}{ Men } & \multicolumn{2}{|c|}{ Women } \\
\hline & Mean & $\mathbf{n}$ & Mean & $\mathbf{n}$ & Mean & $\mathbf{n}$ & Mean & $\mathbf{n}$ & Mean & $\mathbf{n}$ & Mean & $\mathbf{n}$ \\
\hline \multicolumn{13}{|l|}{ Psychosocial work environment } \\
\hline Few stress factors & 0.72 & 848 & 1.48 & 1492 & 1.36 & 784 & 2.34 & 1471 & 0.44 & 916 & 1.20 & 1584 \\
\hline Moderate stress factors & 1.39 & 1289 & 2.47 & 2900 & 1.75 & 1204 & 2.81 & 2955 & 0.68 & 1378 & 1.56 & 3165 \\
\hline Plenty of stress factors & 2.29 & 262 & 3.74 & 494 & 2.38 & 245 & 3.34 & 512 & 1.12 & 274 & 1.96 & 548 \\
\hline Analysis of variance & \multicolumn{2}{|l|}{$F$} & \multicolumn{2}{|l|}{$p$} & \multicolumn{2}{|l|}{$F$} & \multicolumn{2}{|l|}{$p$} & \multicolumn{2}{|l|}{$F$} & \multicolumn{2}{|l|}{$p$} \\
\hline \multicolumn{13}{|l|}{$\begin{array}{l}\text { Main effects } \\
\text { Psychosocial work }\end{array}$} \\
\hline Environment & \multicolumn{2}{|l|}{235.16} & \multicolumn{2}{|l|}{0.001} & \multicolumn{2}{|l|}{51.72} & \multicolumn{2}{|l|}{0.001} & \multicolumn{2}{|l|}{59.15} & \multicolumn{2}{|l|}{0.001} \\
\hline Gender & \multicolumn{2}{|l|}{270.78} & \multicolumn{2}{|l|}{0.001} & \multicolumn{2}{|l|}{183.82} & \multicolumn{2}{|l|}{0.001} & \multicolumn{2}{|l|}{279.46} & \multicolumn{2}{|l|}{0.001} \\
\hline Interaction effects & \multirow{2}{*}{\multicolumn{2}{|c|}{8.03}} & \multirow{2}{*}{\multicolumn{2}{|c|}{0.001}} & \multirow{2}{*}{\multicolumn{2}{|c|}{0.27}} & \multirow{2}{*}{\multicolumn{2}{|c|}{.764}} & \multirow{2}{*}{\multicolumn{2}{|c|}{0.92}} & \multirow{2}{*}{\multicolumn{2}{|c|}{0.397}} \\
\hline $\begin{array}{l}\text { Psychosocial work environment } \\
\times \text { gender }\end{array}$ & & & & & & & & & & & & \\
\hline
\end{tabular}

psychosocial work environment more negatively more often report complaints concerning the indoor environment and more symptoms attributed to the indoor air.

The association of the psychosocial work environment with both complaints of the indoor air and the symptoms attributed to indoor air was noted in both genders, in every age group, among smokers and non-smokers, and respondents with or without an allergic background. An interesting statistically significant interaction effect, however, was found between gender and general symptoms. This suggests that, in a stressful situation, women are more apt to report general symptoms (for example, fatigue, headache, difficulties in concentrating) attributed to indoor air.

The analysis at the workplace level brought out differences in the strength of the association between the psychosocial work environment and the indoor air complaints and symptoms. The association was strongest at the "problem workplaces" - that is, where the prevalence of perceived indoor air problems was the highest.

Mental strain and work related stress thus seem to function as modifying factors between environmental factors and symptoms. ${ }^{89}$ Interestingly, it appears that at least in some cases another interpretation might also be possible. There are some indications in earlier studies that during extensive organisational changes, the general insecurity and anxiety among the staff could be channelled or externalised into indoor air problems. ${ }^{5}$ The indoor air problems may become so-called "good enemies" which help people to cope with the psychological stress originally arising from other causes. Instead of an abstract and overwhelming organisational crisis, an indoor air problem may be a more tangible and safe enemy to complain about and fight with. These findings indicate that the role of the psychosocial work environment in indoor air problems is complicated and certainly requires more research. In order to understand the mechanism and processes behind these observations, qualitative methods and case study procedures ought to complement the traditional epidemiological research. ${ }^{5}$

The strengths of the present study are a large sample size and the response rate $(73 \%)$ which is satisfactory for a study of this type. The limitation of the present study is, however, that the investigated workplaces were not randomly chosen. All of the workplaces in the study sample had suspicions of indoor air problems. The quantity of reported symptoms and complaints about indoor air are thus assumed to be slightly higher than normal.

Women were slightly over-represented in the study sample, and the women reported more work related symptoms than the men. ${ }^{15}$ A similar observation has been reported in several studies. ${ }^{11}{ }^{17} 18$ Gender based differences have been explained by work related factors, for example, the different work tasks and work roles of men and women, factors outside the work, and physiological factors. ${ }^{17}{ }^{18}$ As stated above, there were also gender based differences concerning the reports of the psychosocial work environment. However, gender had only a minor significance to the association between the psychosocial work environment and the symptoms attributed to indoor air.

It may be asked whether the observed associations in the study are possibly confounded with job category effect. The respondents' task in the organisation was inquired in the questionnaire with an open ended question which, unfortunately, was answered only partly by the respondents. Due to the missing data and vague descriptions, it was not possible to construct a reliable job classification.

In occupational health care practice, detailed and comprehensive questionnaires are often difficult or even impossible to use, and therefore compact methods are needed for field work. The present results show that the MM-40 questionnaire, however, keeping in mind the restrictions discussed in

Table 5 The psychosocial work environment and the indoor air complaints and symptoms in the groups of strong multiple association and moderate or weak association

\begin{tabular}{lllll}
\hline & $\begin{array}{l}\text { Strong multiple } \\
\text { association } \\
\text { (mean) }\end{array}$ & $\begin{array}{l}\text { Moderate or weak } \\
\text { association (mean) }\end{array}$ & † value & p value \\
\hline The psychosocial work environment & $7.59(n=733)$ & $7.50(n=10024)$ & 1.37 & 0.172 \\
General symptoms & $2.26(n=506)$ & $1.93(n=6881)$ & 2.93 & 0.004 \\
Mucous membrane symptoms & $2.88(n=496)$ & $2.37(n=6774)$ & 4.27 & 0.001 \\
Dermal symptoms & $1.35(n=556)$ & $1.21(n=7419)$ & 1.81 & 0.072 \\
The complaints on the indoor air & $9.63(n=753)$ & $8.70(n=10257)$ & 5.23 & 0.001 \\
\hline
\end{tabular}


the introduction, brings out the association between the psychosocial work environment and indoor air problems. In this respect, it seems that the MM-40 questionnaire could be useful as a practical screening method in the diagnosis phase when analysing the role of the psychosocial work environment among the different background factors of an indoor air problem. The questionnaire offers a more reliable instrument than the "diagnosis by exclusion", which seems to be a too often-used method when it comes to psychosocial work environment. ${ }^{5}$ However, further studies on the reliability and validity of the psychosocial questions in MM-40 are needed.

Although the MM-40 questionnaire has been widely used in the past years by occupational health personnel, the information from the four questions on the psychosocial work environment has not been fully utilised in practice. One possible reason for this may be the lack of appropriate reference data. The results of the present study can provide a tool for the use of the occupational health services for assessing and interpreting the results of the MM-40 questionnaire surveys which they have conducted on their clients.

The reference data reported in this paper could be used to estimate the conditions at a single workplace: if psychosocial stress factors are emphasised in the survey data of the workplace, the situation in the organisation should be examined more closely. As with any other survey methods, it is impossible to draw far-reaching conclusions on mere numeric values. Clearly exceptional results can, however, be considered as an indicator of a problem. In order to evaluate the significance of the results, more information on the organisation is needed, as well as cooperation and further discussions with the staff. The results should be discussed between the superiors, labour protection staff, and occupational health care personnel, after which feedback should be given to the entire staff. In this way the questionnaire also offers an important instrument which can help to increase employee participation, and consequently, the subjective sense of environmental control in the problem solving process. ${ }^{5}$ The discussions and the systematically investigated and analysed data on the psychosocial factors, alongside technical and physical data, help the multiprofessional team and the employees to understand the situation better and to select and direct necessary measures at the workplace. In some cases, it can be noted that in order to improve the wellbeing of the personnel, it may be necessary to monitor more closely the psychological work characteristics and the organisational functioning, as well as the indoor air quality. There are many suitable methods for carrying out further investigations. For example, interviews, group discussions, and the work conference technique may be useful. The QPSNordic $^{19}$ and the $\mathrm{OSQ}^{20}$ are questionnaire methods available to the occupational health services.

The solving of an indoor air problem requires long term, well organised development work. In order to achieve good results-that is, "healthy employees in a well functioning work environment", it may be necessary to apply restorational measures and interventions, directed at both the technical and psychosocial work environment, and the work organisation. As a result, indoor air problems present a challenge to the occupational health services, various specialists, and the staff of the workplace; demanding, multiprofessional cooperation is required of them.

\section{Authors' affiliations}

M Lahtinen, C Sundman-Digert, K Reijula, Uusimaa Regional Institute of Occupational Health, Helsinki, Finland

\section{REFERENCES}

1 Cox T. Stress, coping and problem solving. Work \& Stress 1987;1:5-14

2 Moreland RL, Levine JM. Problem identification by groups. In: Worchel S, Wood W, Simpson JA, eds. Group process and productivity. Newbury Park: Sage, 1992: 17-47.

3 Engdahl RA, Keating RJ. Strategic problem solving process: a comprehensive model and the need for more focused attention on consensus seeking. Organizational Development Journal 1995;13:80-94.

4 Lyles MA. Formulating strategic problems: empirical analysis and model development. Strategic Management Journal 1981;2:61-75.

5 Lahtinen M, Huuhtanen P, Kähkönen E, et al. Psychosocial dimensions of solving an indoor air problem. Indoor Air 2002;12:33-46.

6 Lahtinen M, Huuhtanen P, Reijula K. Sick building syndrome and psychosocial factors - a review of literature. Indoor Air 1998:4(suppl):32-9.

7 Sandsted E, Tielman S. Samhällsvetenskaplig forskning om sjuka och sunda hus. En litteratursammanställning. Arbetslivsinstitutet, Arbete och hälsä, Vetenskaplig skriftserie 16 [in Swedish]. Stockholm, 1999.

8 Crawford JO, Bolas SM. Sick building syndrome, work factors and occupational stress. Scand J Work Environ Health 1996;22:243-50.

9 Jaakkola JJK. The office environment model: a conceptual analysis of the sick building syndrome. Indoor Air 1998;4(suppl):7-16.

10 Cox T, Griffiths A, Rial-Gonzales E. Research on work-related stress. Luxembourg: European Agency for Safety and Health at Work, 2000.

11 Andersson K. Epidemiological approach to indoor air problems. Indoor Air 1998;4(suppl):32-9.

12 Karasek RA. Job demands, job decision latitude and mental strain: implications for job redesign. Adm Sci Q 1979;24:285-308.

13 Karasek RA, Theorell T. Healthy work. Stress, productivity, and the reconstruction of working life. New York: Basic Books, 1990.

14 Johnson JV. Control, collectivity and the psychosocial work environment. In: Sauter SL, Hurrell JJ Jr, Cooper CL, eds. Job control and worker health. Chichester: John Wiley \& Sons, 1989.

15 Reijula K, Sundman-Digert C. Assessment of indoor air problems at work with a questionnaire. Occup Environ Med 2004:61:33-8.

16 Rantanen J, Kauppinen T, Toikkanen J, et al. Work and health country profiles. Country profiles and national surveillance indicators in occupational health and safety. People and work. Research reports 44. Helsinki: Finnish Institute of Occupational Health, 2001.

17 Burge S, Hedge A, Wilson S, et al. Sick building syndrome: a study of 4373 office workers. Ann Occup Hygiene 1987;31:493-502.

18 Stenberg B, Wall S. Why do women report "sick building symptoms" more often than men? Soc Sci Med 1995:40:491-502.

19 Lindström K, Elo A-L, Skogstad A, et al. User's guide for the QPSNordic. General Nordic questionnaire for psychological and social factors at work. TemaNord 2000. Copenhagen: Nordic Council of Ministers, 2000:603.

20 Elo A-L, Leppänen A, Lindström K, et al. OSQ-occupational stress questionnaire: user's instructions. Helsinki: Finnish Institute of Occupationa Health, 1992. 